\title{
Torrential floods and town and country planning in Serbia
}

\author{
R. Ristić ${ }^{1}$, S. Kostadinov ${ }^{1}$, B. Abolmasov ${ }^{2}$, S. Dragićević ${ }^{3}$, G. Trivan ${ }^{4}$, B. Radić ${ }^{1}$, M. Trifunović ${ }^{5}$, and \\ Z. Radosavljević 6 \\ ${ }^{1}$ University of Belgrade Faculty of Forestry, Department for Ecological Engineering in Protection of Soil and Water \\ Resources Kneza Višeslava 1, 11030 Belgrade, Serbia \\ ${ }^{2}$ University of Belgrade Faculty of Mining and Geology, Belgrade, Serbia \\ ${ }^{3}$ University of Belgrade Faculty of Geography, Belgrade, Serbia \\ ${ }^{4}$ Secretariat for Environmental Protection of Belgrade City, Belgrade, Serbia \\ ${ }^{5}$ Institute of Transport and Traffic Engineering-Center for Research and Designing, Belgrade, Serbia \\ ${ }^{6}$ Republic Agency for Spatial Planning, Belgrade, Serbia
}

Correspondence to: R. Ristić (ratko.risticc@gmail.com)

Received: 12 August 2011 - Revised: 8 November 2011 - Accepted: 14 November 2011 - Published: 2 January 2012

\begin{abstract}
Torrential floods are the most frequent natural catastrophic events in Serbia, causing the loss of human lives and huge material damage, both in urban and rural areas. The analysis of the intra-annual distribution of maximal discharges aided in noticing that torrential floods have a seasonal character. The erosion and torrent control works (ETCWs) in Serbia began at the end of the 19th century. Effective protection from torrential floods encompasses biotechnical works on the slopes in the watershed and technical works on the torrent beds, within a precisely defined administrative and spatial framework in order to achieve maximal safety for people and their property. Cooperation to overcome the conflicts between the sectors of the water resources management, forestry, agriculture, energetics, environmental protection and local economic development groups is indispensable at the following levels: policy, spatial planning, practice, investments and education. The lowest and most effective level is through the Plans for Announcement of Erosive Regions (PAERs) and the Plans for Protection from Torrential Floods (PPTFs), with Hazard Zones (HZs) and Threatened Areas (TAs) mapping on the basis of the hydrologic, hydraulic and spatial analysis of the factors that are important for the formation of torrential floods. Solutions defined through PAERs and PPTFs have to be integrated into Spatial Plans at local and regional levels.
\end{abstract}

\section{Introduction}

Natural or anthropogenic calamities may cause huge material damage and, unfortunately, the loss of human lives (Toya and Skidmore, 2007). The occurrence of natural and anthro- pogenic extreme phenomena all around the world makes us pay more attention to their environmental and economic impacts (Guzzetti et al., 2005; Schmidt et al., 2006; Lerner, 2007). Floods, in all their various forms, are the most frequent natural catastrophic events that occur throughout the world (Berz et al., 2001; Barredo, 2007). Among natural hazards with serious risks for people and their activities, torrential (flash) floods are the most common hazard in Serbia (Ristić and Nikić, 2007) and the most significant regarding huge material damage and loss of human lives. The frequency of these events, their intensity and diffusion in the whole country (Fig. 1) make them a permanent threat with severe consequences to environmental, economic and social spheres. The representative examples are the torrential floods that occurred in the watersheds of the main tributaries of the following rivers in the past $15 \mathrm{yr}$ : the Kolubara (June of 1996; May of 2011), the Great Morava (July of 1999), the Kolubara and the Drina (June of 2001), the South Morava (November of 2007), the West Morava, the Drina and the Lim (November of 2009), the Great Timok (February of 2010), the Pèinja (May of 2010), and the Drina (December of 2010).

Serbia has not been included in the most recent studies that have examined flood hazards within the territory of Europe and globally (Barredo, 2007; Mosquera-Machado and Dilley, 2009). This paper presents the most significant aspects of the phenomenon of torrential floods as the most common natural hazard in Serbia. The first part of this paper presents a map with the spatial disposition of the most destructive torrential floods in the last $60 \mathrm{yr}$, including the results of the analysis of the characteristics of the maximal discharges and some interesting cases of historic torrential floods reconstructed by the "hydraulic flood traces" method. The second part of 
this paper is concerned with a brief history of the Erosion and Torrent Control Works (ETCWs) in Serbia, in the period from 1907 to 2006, along with a review of the legislation pertaining to the issues of erosion and torrent control. The third part of the paper refers to the issues of town and country planning as a tool for mitigating the harmful effects of erosion and torrential floods.

The main objectives of this paper are to present the integral notion of the problem of torrential floods in Serbia while highlighting some possible improvements to the process of town and country planning as a useful means for more effective torrential watershed management.

\subsection{Torrential floods and erosion}

Torrential (flash) flood represents a sudden appearance of maximal discharge in a torrent bed with a high concentration of sediment. In extreme cases, the two-phase fluid flows out from the torrent bed with enormous destructive energy. The two-phase fluid (water and sediment) can contain fractions ( $60 \%$ of total volume) with different granulations ranging from clay particles to rock fragments, diameters of up to $5.0 \mathrm{~m}$ and a total mass of over 200 tons (Jevtić, 1978).

Torrential watershed is a hydrographic entity that involves the beds of the mainstream and its tributaries, and the gravitating surfaces with erosion processes at a certain level of intensity. The attribute "torrential" refers to any watershed with a sudden appearance of maximal discharge with a high concentration of sediment, regardless of the size and category of the stream (Ristić and Malošević, 2011a). A total of 9260 torrential watersheds were registered in Serbia on the basis of an investigation carried out from 1930 to 1974 (Gavrilović, 1975).

Torrential floods that once occurred rarely during the predevelopment period have now become more frequent and destructive due to the transformation of the land usage in the watersheds from rural to urban land usage (Kusky, 2010). The decrease of surfaces covered with forest vegetation, along with urbanization and inadequate agricultural measures, are some of the negative aspects of human activities that cause torrential floods. Due to these activities, former discharges with a 100 -yr recurrence interval have become events with a 20-year recurrence interval (Ristić et al., 2006). Along with the watershed development, there are changes in its hydrological regime that increase the torrential flood volume. The soil and vegetation cover directly affects the intensity of the surface runoff by creating "losses" of precipitation through the processes of interception, evaporation, transpiration and infiltration (Ristić and Macan, 1997a, 2002). The eroded soil becomes compacted with an insufficient amount of nutrients and organic matter. The infiltration rates and water-storage capacity of the soil profile are reduced, which, in turn, increases the overland flow and erosion. The amount of surface runoff depends on the total precipitation, the type of land usage, and the characteristics of the vegetation cover and the air and water capacity of the soil (Ristić et al., 2001; Nondedeu et al., 2006; Nondedeu and Bédécarrats, 2007; Szendreine-Koren and Nemeskeri, 2007).

The climate, along with the specific characteristics of the relief, distinctions of the soil and vegetation cover, severe erosion processes and social-economic conditions result in the frequent occurrence of torrential floods. Erosion processes of different categories of destruction are present in $76355 \mathrm{~km}^{2}$ (86.4\% territory of Serbia) in Serbia. The average annual production of erosive material in the territory of Serbia is $37.25 \times 10^{6} \mathrm{~m}^{3}$, in other words, $487.85 \mathrm{~m}^{3} \times \mathrm{km}^{-2}$, which is 4.88 times more than the geological (natural) erosion. The average rate of soil formation on the slopes in Serbia is $0.1 \mathrm{~mm} \mathrm{yr}^{-1}$. Geological (natural) erosion is the action of wind, water, ice and gravity in wearing away the soil at a rate smaller than $0.1 \mathrm{~mm} \mathrm{yr}^{-1}\left(\leq 100 \mathrm{~m}^{3} \times \mathrm{km}^{-2} \mathrm{yr}^{-1}\right)$. It is a relatively slow, continuous process unlike accelerated erosion, which produces a rate of soil loss higher than $0.1 \mathrm{~mm} \mathrm{yr}^{-1}\left(>100 \mathrm{~m}^{3} \times \mathrm{km}^{-2} \mathrm{yr}^{-1}\right)$ due to human activities (Kostadinov, 2008).

Severe and excessive erosion processes cover $35 \%$ of the territory of Serbia (IWRMJC̀, 2001). With local economic development, soil erosion becomes more frequent and severe (Ananda and Herath, 2003; Bakker et al., 2005). The construction of roads and residential areas and the inappropriate use of agricultural and forest land contribute to the concentration of fast surface runoff, as well as sediment transportation from the gravitating surfaces to the channel network. The roads interact positively with clear cutting. They modify the hill slope flow paths and cause faster delivery of the water to the channels during storm events with the conversion of the subsurface flow into surface flow (Jones and Grant, 1996). Such flows contribute 20 to 60 times more sediment (unsealed roads) than undisturbed forest surfaces and about 10 times more sediment than harvested areas (Motha et al., 2003). Clear cutting and removal of the vegetation influence the water balance by affecting evapotranspiration and possibly snow accumulation and melt. These activities increase the peak discharge by as much as $50 \%$ in small basins and $100 \%$ in large basins (Jones and Post, 2004). Timber harvesting has the potential to increase the total flow and lengthen the duration of larger flows while enabling sediment movement (Troendle and Olsen, 1994). Steep terrains without vegetation are particularly prone to increased surface runoff and erosion (Wipf et al., 2005), like ski runs with decreased surface roughness and increased velocity of runoff and sediment yield (Fattorini, 2001; Freppaz et al., 2002; Ristić et al., 2011b). 


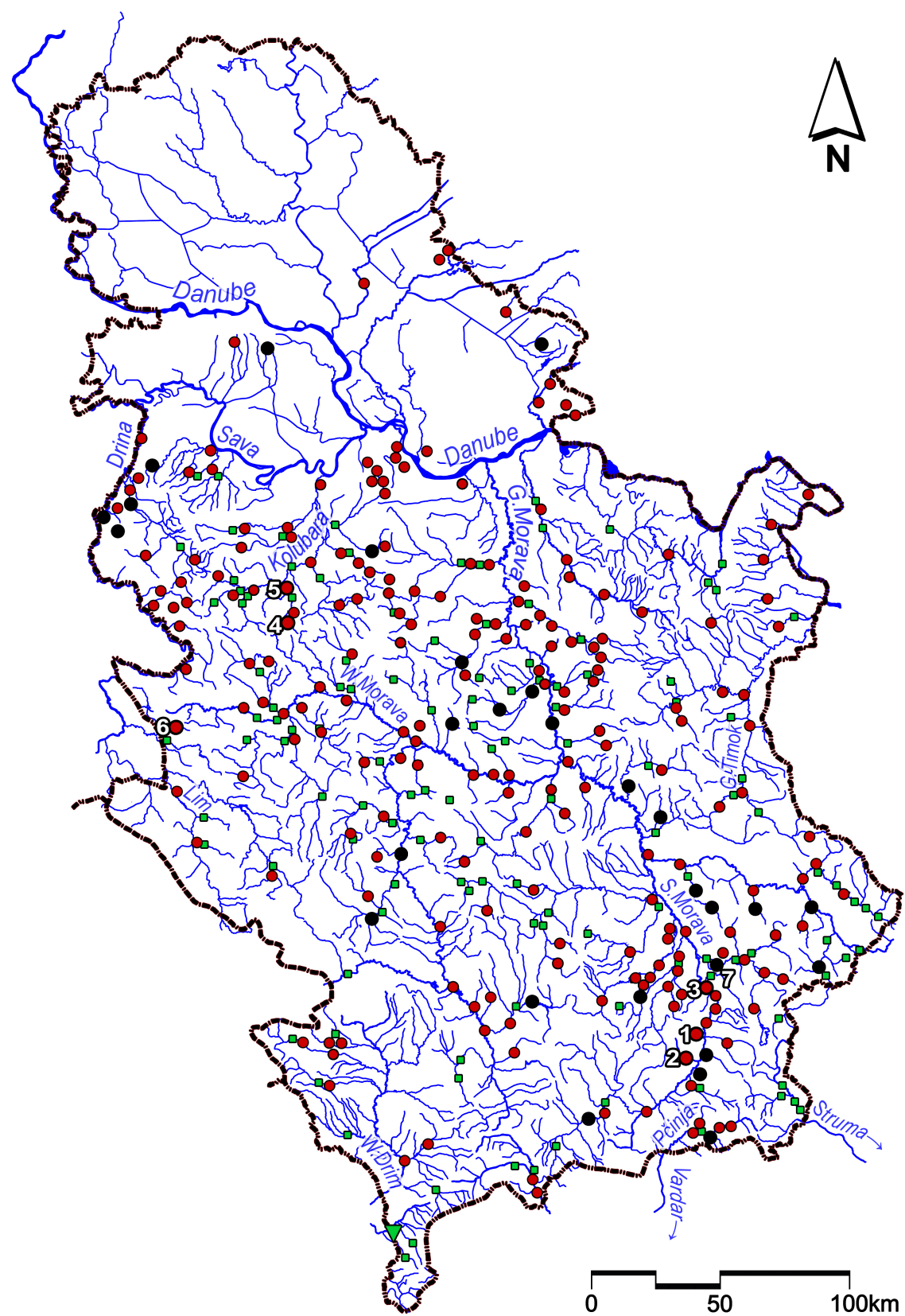

Fig. 1. Spatial disposition of the most destructive torrential floods in Serbia from 1950 to 2010 (- material damage and loss of human lives; - material damage); - control profiles from the RHMOS observation system; $\mathbf{\nabla}$ - profile Orćuša, the Plavska River (refers to Fig. 2); 1-7 locations of the profiles (refers to Fig. 4).

\section{Torrential floods in Serbia}

\subsection{Characteristics of maximal discharges in Serbian torrential watersheds}

The characteristics of the maximal discharges in Serbian torrential watersheds were studied by data processing with 128 control profiles (Fig. 1), which were equipped with au- tomatic water-level recorders (Ristić et al., 2011c). The observation system was under the supervision of the Republic Hydro Meteorological Office of Serbia (RHMOS). At most profiles measurements started in 1953, with a few profiles starting in 1946, and our investigation confined to the measurements of up to 2007 . The study area $\left(66873 \mathrm{~km}^{2}\right)$ covers the central part of Serbia, south of the rivers Sava and Danube (Fig. 1). The ranges of values of the main physical 


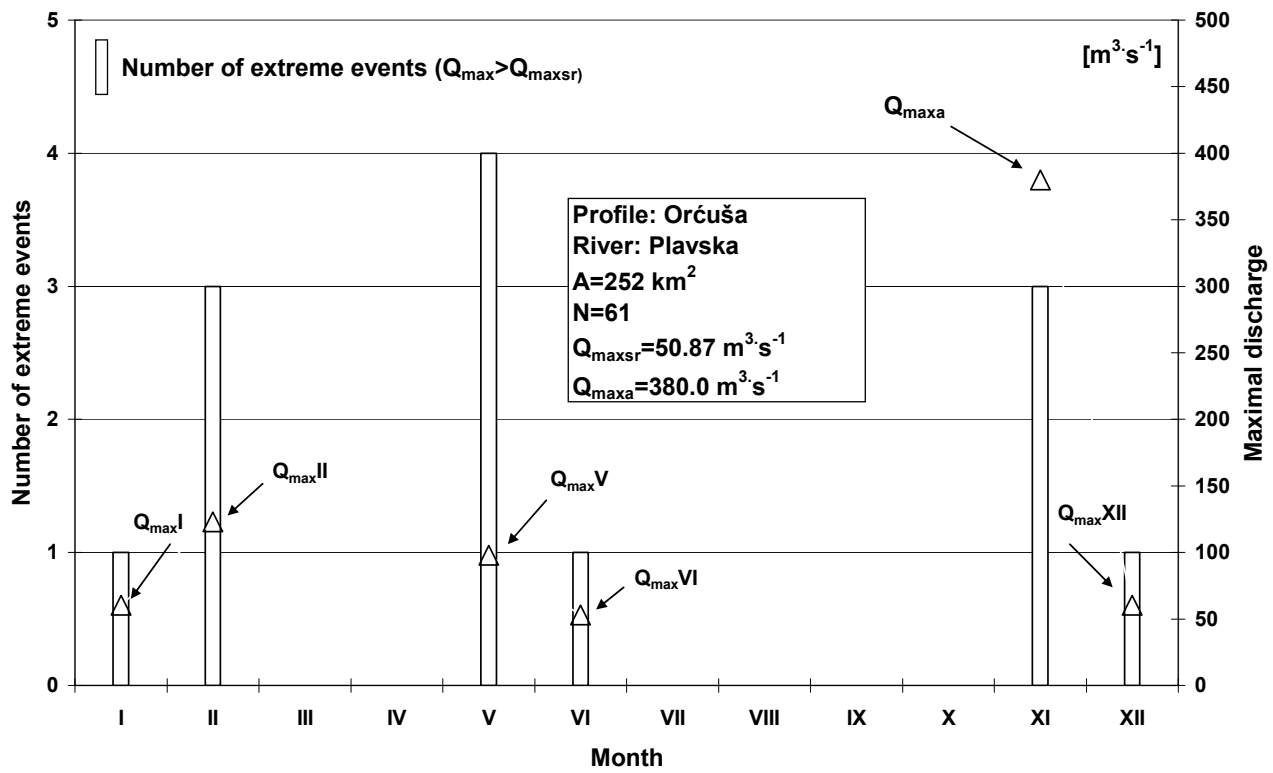

Fig. 2. The Orćuša Profile, the Plavska River; the number of extreme events $\left(Q_{\max }>Q_{\max }\right.$ sr $)$ per month; monthly maximal discharges and absolute maximal discharge (the profile location is presented in Fig. 1).

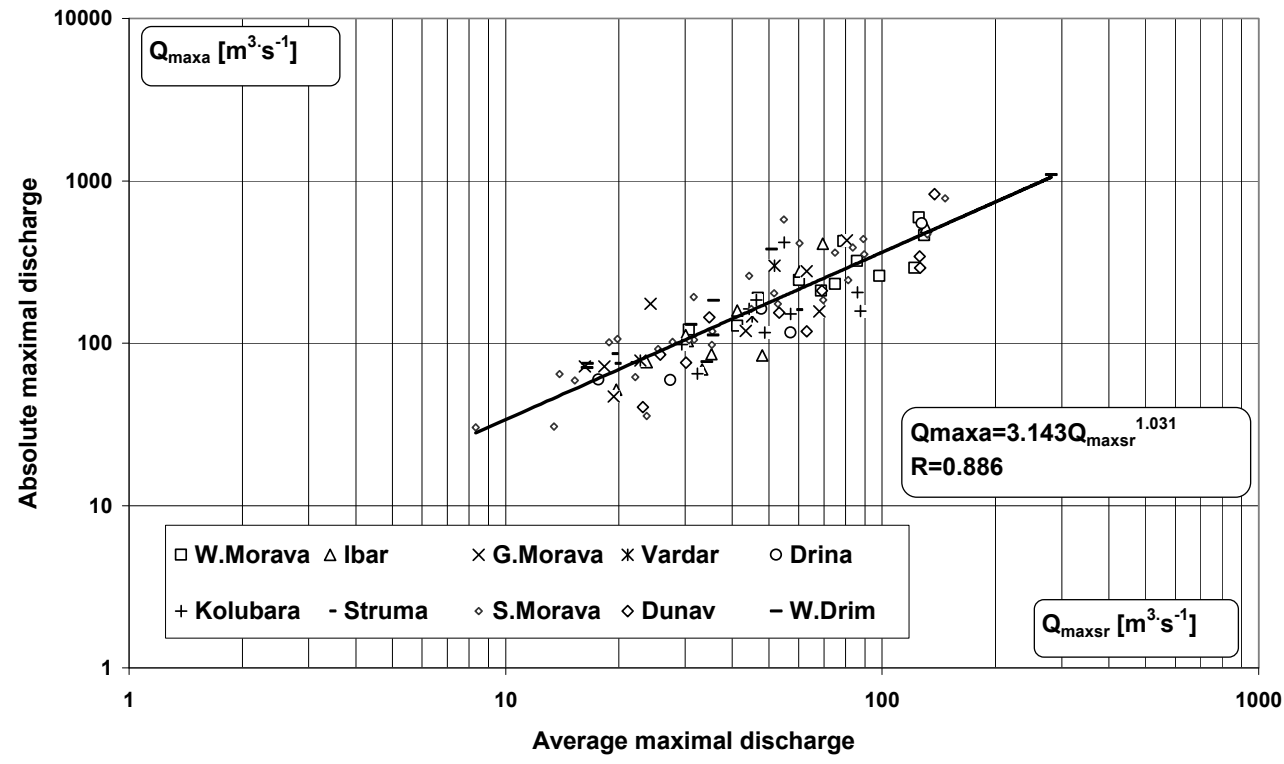

Fig. 3. Relation $Q_{\max a}=f\left(Q_{\max s r}\right)$.

characteristics of the investigated watersheds are presented in Table 1. The recorded maximal discharges were the consequence of the fast surface runoff generated in the following ways: short intensive rain, long less intensive rain and snow melt, and the coincidence of rain and snow melt. The torrential floods in Serbia can be caused in all the above mentioned ways, but it is possible to recognize the dominant way in certain watersheds. The number of extreme events in individual months (maximal discharge $\mathrm{Q}_{\max }$ over the referential threshold $\mathrm{Q}_{\max \text { sr }}, \mathrm{Q}_{\max }>\mathrm{Q}_{\max \text { sr }}$ ) was analyzed for all the observed years. The average maximal discharge $\mathrm{Q}_{\max }$ sr was determined as the mean value of all the recorded annual maximal discharges $\mathrm{Q}_{\max }$ i in the observed years $\mathrm{N}$.

$\mathrm{Q}_{\max \mathrm{sr}}=\frac{\sum_{i=1}^{N} \mathrm{Q}_{\max \mathrm{i}}}{N}$ 
Table 1. The ranges of values of the main physical characteristics of the investigated watersheds.

\begin{tabular}{lll}
\hline Parameter & Min. value & Max. value \\
\hline A-drainage area $\left[\mathrm{km}^{2}\right]$ & 10 & 1268 \\
L-the length of main channel [km] & 6.4 & 93.2 \\
Pp-peak point [m.a.s.l] & 452 & 2017 \\
Cp-confluence point [m.a.s.1] & 87 & 986 \\
Sa-main channel slope [\%] & 0.76 & 7.84 \\
Sw-weighted slope of main channel [\%] & 0.26 & 4.66 \\
Sm-mean watershed slope [\%] & 8.98 & 45.70 \\
Lc-the shortest distance from confluence point to watershed centroid [km] & 3.4 & 46.5 \\
Wm-mean width of the watershed [km] & 1.32 & 19.40 \\
\hline
\end{tabular}

Table 2. Basic characteristics of the reconstructed torrential floods.

\begin{tabular}{|c|c|c|c|c|c|c|}
\hline Water course & Profile & $\begin{array}{l}\text { Date of } \\
\text { appearance }\end{array}$ & $\begin{array}{l}\mathrm{A} \\
{\left[\mathrm{km}^{2}\right]}\end{array}$ & $\begin{array}{l}\mathrm{Qmax}_{\max } \\
{\left[\mathrm{m}^{3} \times \mathrm{s}^{-1}\right]}\end{array}$ & $\begin{array}{l}\mathrm{qmax} \mathrm{sp} \\
{\left[\mathrm{m}^{3} \times \mathrm{s}^{-1} \times \mathrm{km}^{-2}\right]}\end{array}$ & $\begin{array}{l}\text { Precipitation duration } \\
\text { / Mean intensity }\end{array}$ \\
\hline 1-Lještarska & Vladic̀in Han & 25.07 .1982 & 2.64 & 16.16 & 6.12 & $90 \mathrm{~min} ; 1.17 \mathrm{~mm} \mathrm{~min}^{-1}$ \\
\hline 2-Kalimanska & Vladic̀in Han & summer 1929 & 16.04 & 149.0 & 9.30 & / \\
\hline 3-Sejanic̀ka & Grdelica & 02.07 .1983 & 12.51 & 62.75 & 5.02 & $90 \mathrm{~min} ; 1.01 \mathrm{~mm} \mathrm{~min}^{-1}$ \\
\hline 4-Manastirica & Breždje & 13.06.1996 & 29.5 & 154.9 & 5.25 & $180 \mathrm{~min} ; 0.75 \mathrm{~mm} \mathrm{~min}^{-1}$ \\
\hline 5-Ribnica & Paštrić & 13.06.1996 & 104 & 418.08 & 4.02 & $180 \mathrm{~min} ; 0.75 \mathrm{~mm} \mathrm{~min}^{-1}$ \\
\hline 6-Kamišna & Mokra Gora & 27.05.2007 & 26.94 & 76.3 & 2.83 & $120 \mathrm{~min} ; 0.83 \mathrm{~mm} \mathrm{~min}^{-1}$ \\
\hline 7-Vlasina & Vlasotince & 26.06 .1988 & 972 & 780 & 0.80 & $240 \mathrm{~min} ; 0.34 \mathrm{~mm} \mathrm{~min}^{-1}$ \\
\hline
\end{tabular}

- $\mathrm{Q}_{\max \text { sr }}$ - the mean value of all the recorded maximal discharges $\mathrm{Q}_{\max }$ i in the observed years $\mathrm{N}$,

- $\mathrm{Q}_{\max } \mathrm{i}$ - the recorded maximal discharge in the observed year (annual maximum),

- $\mathrm{N}-$ the number of observed years,

- $\mathrm{Q}_{\max \text { a }}$ - the absolute recorded maximal discharge, and

- $\mathrm{Q}_{\max } \mathrm{I}-\mathrm{XII}$ - the recorded maximal discharges in certain months.

The analysis of the intra-annual distribution of maximal discharge allowed the indication of critical parts of the year with frequent appearances of extreme events. According to this analysis, the appearance of maximal discharges in torrential watersheds has a seasonal character. In other words, the number of extreme events is larger in certain parts of the year. The critical periods are the end of spring (from May to the first half of June) and the end of winter (from February to the first half of March). The period from May to the first half of June was marked as the primary maximum in most watersheds (the Great Morava River, the South
Morava River, the West Morava River, the Ibar River, the Kolubara River, the White Drim River, the Vardar River and the Struma River). In this period, the high water levels were the result of intensive rainfall of a few-hours duration. The daily and monthly maximums of precipitation were recorded at almost all the rain-gauge stations in Serbia in the period from May to June. The period from February to the first half of March was noted as the secondary maximum. The absolute maximal values of discharge $Q_{\max }$ a were recorded in the periods with frequent extreme events at most profiles. However, the values of $\mathrm{Q}_{\max }$ a were also recorded in the periods with rare extreme events at some profiles, as a consequence of specific climate and hydrological conditions including: a sudden rise in air temperature during the winter that caused snow melt and often coincided with a long low intensity rain; snow precipitation at the end of winter followed by a sudden rise in air temperature and fast melting; along with a few sequential rain events during the summer that caused a reduction of infiltration and water storage capacity of the soil. The intra-annual distribution of the maximal discharges combined with the number of extreme events are presented in diagrammatic form (Fig. 2). Each diagram contains: the names of the profile and the river, the size of the watershed $\mathrm{A}$, the number of observation years $\mathrm{N}$, the average maximal discharge $\mathrm{Q}_{\max \text { sr }}$, the absolute 
maximal discharge $\mathrm{Q}_{\max }$ a and the number of extreme events (y axes in Fig. 2) in individual months. Also, the recorded maximal discharges $\mathrm{Q}_{\max } \mathrm{I}-\mathrm{XII}$ in individual months are presented (e.g. Fig. 2: the recorded maximal discharge was $Q_{\max } I=60.5 \mathrm{~m}^{3} \mathrm{~s}^{-1}$ in January, $\mathrm{Q}_{\max } \mathrm{II}=123 \mathrm{~m}^{3} \mathrm{~s}^{-1}$ in February, $\mathrm{Q}_{\max } \mathrm{V}=97.9 \mathrm{~m}^{3} \mathrm{~s}^{-1}$ in May, $\mathrm{Q}_{\max } \mathrm{VI}=52.9 \mathrm{~m}^{3} \mathrm{~s}^{-1}$ in June and $Q_{\max } X I I=60.5 \mathrm{~m}^{3} \cdot \mathrm{s}^{-1}$ in December). All the monthly maximums overpass $\mathrm{Q}_{\max \mathrm{sr}}=50.87 \mathrm{~m}^{3} \mathrm{~s}^{-1}$. The largest number of extreme events $Q_{\max }>Q_{\max \text { sr }}$, i.e. 4 occurrences, were recorded in May; and the absolute maximal discharge $\mathrm{Q}_{\max \text { a }}$ of $380 \mathrm{~m}^{3} \mathrm{~s}^{-1}$ was recorded in November.

The relationship between the maximal discharges is represented by a power function (Fig. 3):

$\mathrm{Q}_{\max \mathrm{a}}=3.143 \times \mathrm{Q}_{\max \text { sr }}$

\subsection{Historical cases of torrential floods reconstructed by the "hydraulics flood traces" method}

Some of the more interesting events of historic torrential floods are presented in Table 2, showing their basic characteristics. The sizes of the investigated watersheds range from $A=2.64 \mathrm{~km}^{2}$ to $A=972 \mathrm{~km}^{2}$. The discharges per unit area are presented in a diagram (Fig. 4). The main characteristics of the presented events are: the steepness of the torrent beds, with a main $\mathrm{S}_{\mathrm{a}}=5.74-13.45 \%$ channel slope; huge parts of the watersheds occupied by bare lands, degraded forests and agricultural land; shallow, skeletal soil with a low infiltration capacity; excessive erosion processes; the duration of rain events that range from 90 to $240 \mathrm{~min}$; and the intensity that has a range of $I=0.34$ to $I=1.17 \mathrm{~mm} \times \mathrm{min}^{-1}(340$ $1170 \mathrm{~m}^{3} \times \mathrm{km}^{-2}$ ). The consequence of these characteristics was the sudden appearance of torrential floods and a high content of sediment and destructivity.

The value of the maximal discharge is the basic input data for the design of protective structures in torrential beds (check-dams, overflows, regulations). The determination of the maximal discharge in a torrential watershed requires a careful approach as we must bear in mind some specific conditions, including the steepness of the slopes of the terrain and the torrent bed, the fast concentration of runoff and the transport of huge quantities of sediment. Hydrologic practitioners in Serbia use a control model known as "curves of maximal discharges per unit area" for the calculated values of the maximal discharges in watersheds ranging from 10 to $100000 \mathrm{~km}^{2}$ (Janković and Malošević, 1989). The model is based on statistical processing of the recorded data on maximal discharges observed for more than $30 \mathrm{yr}$. However, the interval for watersheds $A<10 \mathrm{~km}^{2}$ has not been defined due to the lack of control profiles in small watersheds within the RHMOS observation system. Because they are created by graphic interpolation, the curves of maximal discharges per unit area (Fig. 4) are not reliable for the $A=1-10 \mathrm{~km}^{2}$ interval. This served as the source of our motivation to start collecting the data on maximal discharges per unit area in the watersheds ranging from $A=1$ to $A=10 \mathrm{~km}^{2}$, with the remit of reconstruction of extreme hydrologic events using the "hydraulics flood traces" method.

\section{State of the art in the erosion and torrent control in Serbia}

\subsection{Erosion and torrent control works}

The erosion and torrent control works (ETCWs) in Europe started around the middle of the 19th century. They started at the end of 19th century in Serbia but began as an organized activity in 1907. In the period from 1907 to 2006, significant scope of works were performed (Kostadinov, 2007), including technical works $\left(1501656 \mathrm{~m}^{3}\right.$-check dams, bank protective structures, torrent training) and biotechnical works (120 987 ha-afforestation, forest protective belts, silt-filtering strips, grassing, terracing and contour farming).

In the period from 1961 to 1988 , there was the greatest scope of the ETCWs. The average amount of funds allocated for that purpose was $9.68 \times 10^{6} €$ per yr. The dynamics of the works performed from 1994 to 2000 was accompanied by a large drop of funding (on average $0.248 \times 10^{6} €$ per yr), as a result of the weakening of the economy, the falling apart of the former Yugoslavia and the war. From 2002 to 2007, the amount of money invested in ETCWs was $1.045 \times 10^{6}$ €per yr (Ristić and Nikić, 2007). According to the Basic Plan of Water Resources Management of Serbia (IWRMJC̀, 2001), it is necessary to perform ETCWs on an area of 43700 ha and technical works on a volume of $344314 \mathrm{~m}^{3}$ in the next 20 yr. By 2050, biotechnical works are planned on an area of $160100 \mathrm{ha}$ and the volume of planned technical works reaches $1357700 \mathrm{~m}^{3}$. This requires an investment of about $18.7 \times 10^{6} €$ per yr. The priority is the protection of settlements and road networks from torrential floods and erosion control in watersheds of water supply system reservoirs.

The most significant investor in erosion and torrent control in Serbia is the State-owned company "Serbian Waters". There are no developed concepts in the field of agriculture for sustainable use of land on slopes with an erosion control function. The State-owned company "Serbian Forests" performs afforestation, but not with the emphasis on erosion and torrent control. The Directorate for Forests (within the Ministry of Agriculture, Forests and Water Resources Management) treats the problem of erosion control as a minor issue. The State-owned company "Serbian Waters" has jurisdiction over all water streams in a territory of $55953 \mathrm{~km}^{2}$ and "Serbian Forests" manage $19083 \mathrm{~km}^{2}\left(9057 \mathrm{~km}^{2}\right.$ of state forests and $10026 \mathrm{~km}^{2}$ of private forests). However, there are no examples of joint activity in the protection from erosion and torrential floods. Paradoxically, although the above three areas belong to the same ministry, there is no cooperation among them on a horizontal level. Even though large hydropower systems are highly vulnerable to the deposition 


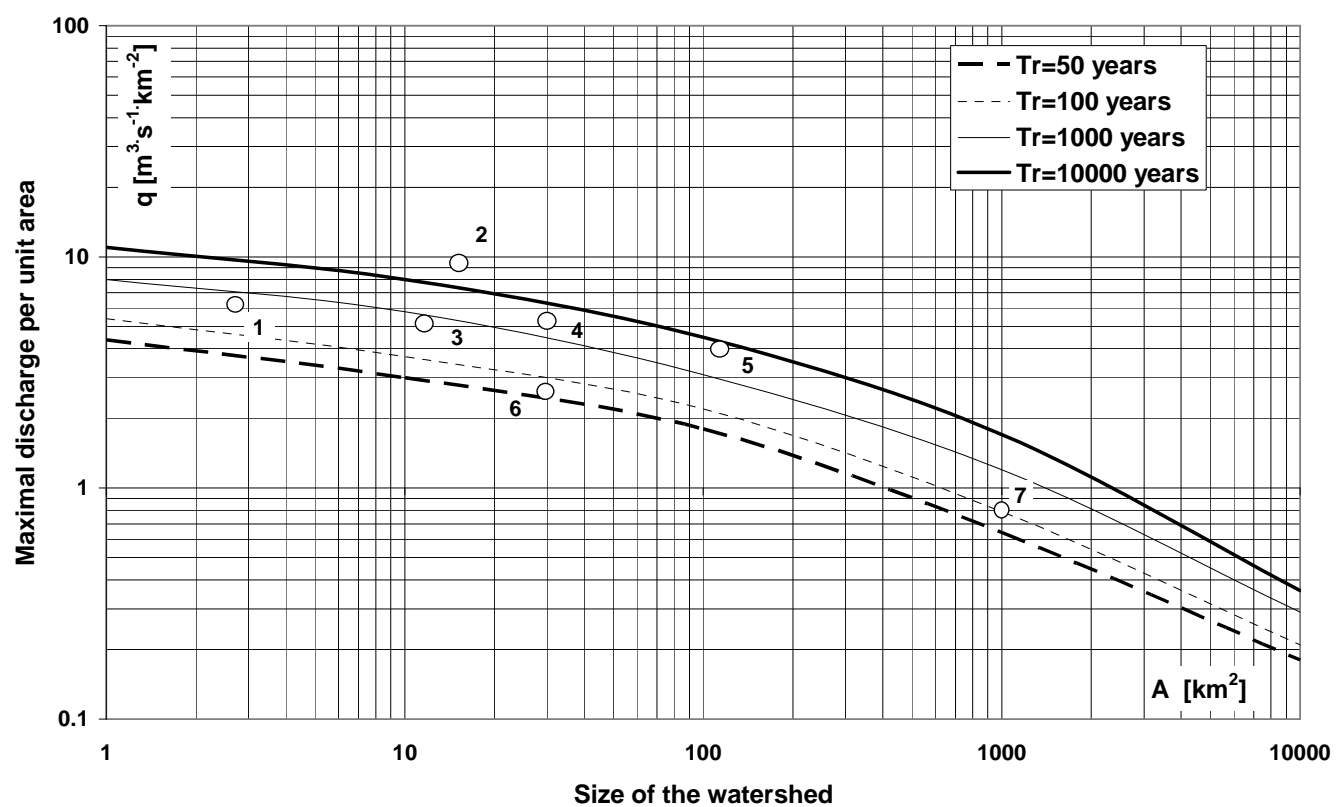

Fig. 4. Maximal discharges per unit area for some extreme events (1-The Lještarska River; 2-The Kalimanska River; 3-The Sejanička River; 4-The Manastirica River; 5-The Ribnica River; 6-The Kamišna River; 7-The Vlasina River). The locations of profiles are presented in Fig. 1

of eroded material during torrential floods, the Ministry of Infrastructure and Energetics does not recognize the need for erosion and torrent control.

\subsection{Serbian and Yugoslav legislation in the field of erosion and torrent control}

Until 1930, in the Kingdom of Yugoslavia there were no regulations or legislation in the field of erosion and torrent control. However, ECTWs were performed during that period on the basis of the existing regulations from the period of Austria-Hungary, the Kingdom of Serbia and the Kingdom of Montenegro (Kostadinov et al., 1999). The "Law of Torrent Control" was passed in 1930. It was the first law which provided the definitions of torrent and watershed, as well as some system resolutions of torrential control financing. The first regulation after the Second World War was passed in 1952 named "The Law on the protection of soil from leaching and rockslides in the region of Grdelička Gorge and Vranjska Valley". A step further was "The Law on Erosion and Torrent Control" that was passed in 1954, which enabled the performing of erosion control works on the land threatened by erosion, irrespective of the ownership of the land.

In the period 1965-1978, no specific laws regarding the issues of Erosion and Torrent Control were brought, and any issues were partially regulated by other laws, including "The Water Law", 1967, 1975; "The Law on Agricultural Land Use”, 1965, 1974; “The Law on Capital Construction”, 1973;
"The Forest Law", 1974; "The Railway Law", 1975; "The Law on Security in Railway Traffic", 1977; and "The Mining Law", 1978. "The Water Law" passed in 1975 was the most complete legal regulation regarding erosion and torrent control. Some of its particularly interesting provisions stipulated that any works of a large scale (dams, roads, etc.) could not be performed without previous projects and special funds provided for erosion and torrent control (by "self-managing communities of interest", following the principles of solidarity and mutual assistance). The structures for erosion and torrent control were classified as protective structures and put in line with other water management structures, i.e. classified as water management activities of special social interest.

Erosion and torrent control problems were dealt with in later Water Laws passed in 1989 and 1991 (OG-The Official Gazette of the Republic of Serbia, No. 46/1991) and 2010 (OG, No. 30/2010). It can be argued that, in comparison with the previous Water Laws, the latest Laws, especially "The Water Law" passed in 2010, represent a step backwards. Namely, the issues of erosion and torrent control are mentioned in only a few Articles. The regulations of the Law regarding erosion and torrent control are enforced and applied by municipal authorities, which often have no organizational or financial capabilities to execute the Law. 


\section{Town and country planning as a tool for mitigation of the impacts of torrential floods}

Water resource planning in Serbia is one of the most important aspects of spatial planning, especially in the fields of flood protection and environmental protection. The harmonization of the national legislation with European Union directives introduced the obligation to produce flood hazard maps, flood risk maps and flood risk management plans within "The Water Law" passed in 2010. However, more detailed methodological recommendations for developing such plans were not defined by this law. Although the latest Serbian Water Law accepted the basic principles of the "Directive 2007/60/EC on the assessment and management of flood risks" (Official Journal of the European Union, 6 November 2007), its shortcoming is the lack of a classification of various flood types. The Serbian Water Law identifies only river floods, whereas the Directive 2007/60/EC lists several types of floods, including river floods, flash floods, urban floods and sea floods in coastal areas (pg. 28, paragraph 10).

Flood protection in the Republic of Serbia is at a satisfactory level on big rivers (the Danube, the Sava, the Drina, the Great Morava, etc), with 29 large surface reservoirs, more than $3550 \mathrm{~km}$ of embankments and numerous river regulations (Republic Agency for Spatial Planning, 2010). However, a large number of settlements, infrastructure systems, industrial plants as well as huge surfaces of agricultural land are endangered by torrents, so it is very important to create legal, spatial planning and technical documents in order to predict hazards and provide adequate protection measures.

Effective torrential watershed management (ETWM) is evaluated by maximum safety, avoidance or mitigation of damages, environmental protection and support of local sustainable economic development. One of the most important segments of ETWM is watershed restoration to its optimal hydrologic state in order to reduce flood discharge and enrich both low flow and average discharges in springs and streams by increasing groundwater recharge. Restoration of torrential watersheds involves biotechnical works on slopes and technical works in the channel network, coordinated within a precisely defined administrative and spatial framework. Cooperation and overcoming of conflicts between the sectors of water resources management, forestry, agriculture, energetics, environmental protection and local economic development are indispensable at the following levels: policy, spatial planning, practice, investments and education.

The lowest and the most effective level of planning is through Plans for Announcement of Erosive Regions (PAERs) and the Plans for Protection from Torrential Floods (PPTFs), with Hazard Zones (HZs) and Threatened Areas (TAs) mapping. HZs are sources of impacts (fast surface runoff and sediment) and TAs are locations under the influence of impacts. TAs in most torrential watersheds in Serbia are located in the downstream sections within settlement zones. The morphology of narrow torrent valleys, characteristically with steep downhill, influences the development of infrastructure and residential areas in the proximity of streams and exposes them to the destructiveness of torrential floods. Municipalities are required to make PAERs and PPTFs, applying methodology prescribed by the Ministry of Agriculture, Forestry and Water Resources Management (1998). PAERs enable implementation of erosion control measures to the level of cadastre parcels in order to restrain further soil degradation caused by inadequate land use. The technical basis for determination of HZs on a municipal territory are identified and declared "erosion zones" (soil surface overtaken by apparent processes of erosion or without apparent erosion, which might occur due to a change in land use). Land owners or users are obliged to apply the following measures: administrative restrictions (straight row farming down the slope, clear cuttings on slopes, grazing on eroded surfaces) and mandatory practices (contour or terrace farming, conversion of crop fields into grass fields, reclamation of degraded pastures, afforestation of bare land, conversion of annual to perennial crops, limited and controlled cutting). PPTFs enable the determination of a flood extent and endangered sections in riparian zones, maximal discharge and water depth. Also, PPTFs oblige municipal authorities to make appropriate action plans with precisely defined responsible persons, other participants and activities if a torrential flood occurs. PPTFs prescribe a ban on the construction of residential and infrastructure objects in flood zones.

The design of such practices is explored through a case study of the experimental watershed of the Manastirica River, which experienced a catastrophic torrential flood in June 1996. This investigation is also concerned with the analysis of impacts (erosion and torrential floods) under the actual and planned conditions of the watershed (after restoration). The planned restoration works involve biotechnical (reforestation of eroded or abandoned arable land, forest protective belts, silt filtering strips, contour farming and terracing), technical (check dams and torrent training works) and administrative measures prescribed through PAERs and PPTFs. The consequences of land use changes were analyzed on the basis of field investigations, usage of aerial and satellite photo images, topographic, geological and soil maps. The land use classification was made on the basis of the CORINE methodology (EEA, 1994). Area sediment yields and the intensity of erosion processes were estimated on the basis of the "Erosion Potential Method" (EPM). This method was created, developed and calibrated in Serbia (Gavrilović, 1972) and it is still in use in all the countries that originated from the former Yugoslavia. The historical maximal discharge $\left(\mathrm{Q}_{\operatorname{maxh}}\right)$ was reconstructed by the "hydraulics flood traces" method (Ristić et al., 1997b). The determination of maximal discharge $\left(\mathrm{Q}_{\max } \mathrm{c}\right)$, under hydrological conditions after the restoration of the watershed, was performed using a synthetic unit hydrograph theory and Soil Conservation Service (SCS) methodology (SCS, 1979; Chang, 2003). This is the most frequently used procedure in Serbia for the computation of 


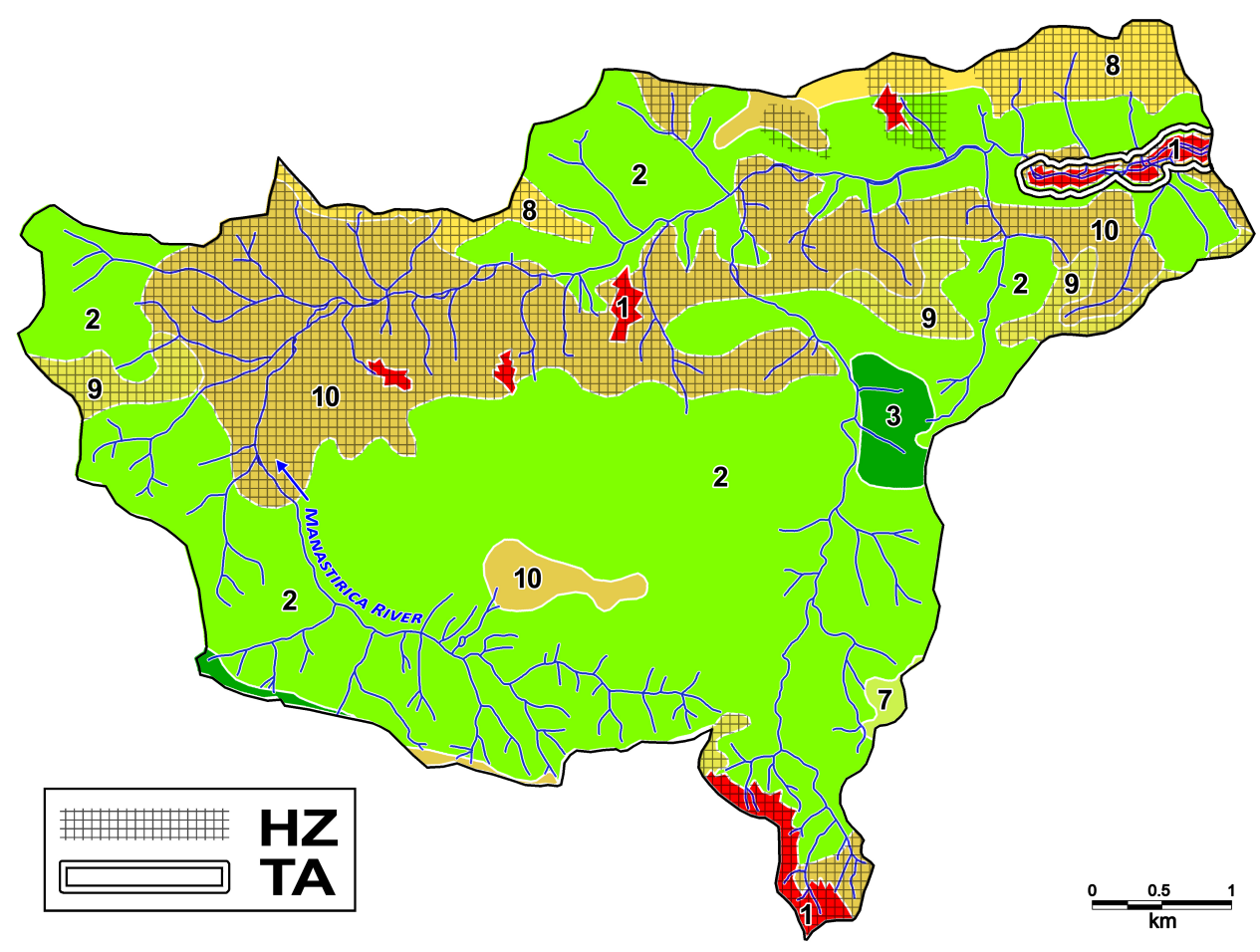

Fig. 5. HZ (Hazard Zones), TA (Threatened Areas) and LU (Land use) in the watershed of the Manastirica River: 1 - Discontinuous urban fabric; 2 - Broad-leaved forest; 3 - Coniferous forests; 7 - Natural grasslands; 8 - Complex cultivation patterns; 9 - Pastures; 10 - Land principally occupied by agriculture, with significant areas of natural vegetation (location of the watershed is presented in Fig.1-point 4).

maximal discharges at small, ungauged watersheds, enriched by a regional analysis of lag time (Ristić, 2003), internal daily distribution of precipitation (Janković, 1994) and classification of soil hydrologic classes (Djorović, 1984). The data on the maximal daily precipitation was provided by the RHMOS observation system (1945-2010).

HZs on the Manastirica River watershed (Fig. 5) occupy $32.68 \%$ of the total area $\left(9.78 \mathrm{~km}^{2}\right)$, while the TA occupies $1.34 \%$ of the total area $\left(0.4 \mathrm{~km}^{2}\right)$. HZs involve settlements, access roads, degraded pastures and arable land on slopes (surfaces marked 1, 8, 9, 10; on Fig. 5) as the most significant sources of sediment and fast surface runoff. The soil in HZs is eroded, compacted and characterized by a reduced water storage capacity. The construction of roads and houses in settlements, inappropriate use of agricultural land (straight raw farming, overgrazing) and forestry activities (clear cutting, removal of timber) enforce the intensity of erosion processes, fast surface runoff and sediment transport. The transfer of impacts from HZs occurs on steep slopes and through the torrent beds of the Manastirica River and its tributaries, with the following effects: development of erosion (sheet erosion, furrows, gullies, etc.), transport of sediment, fast concentration of surface runoff, flood wave formation, flooding of riparian zones, demolishing of houses and bridges, filling of road culverts with sediment, and destruction of the road system. The TA of the Manastirica River watershed is positioned on the downstream section, at the watershed outlet, in the zone of the village of Breždje (Fig. 5). The torrent valley is narrow (on average $200 \mathrm{~m}$ ), with a steep slope downhill (about $35 \%$ ) and more than 200 houses, roads and infrastructure systems (water supply, electric power supply and sewer) in the proximity of the Manastirica River (some houses are just 15-20 $\mathrm{m}$ away from the torrent bed). The village of Breždje was flooded in June 1996, after heavy rain of $135 \mathrm{~mm}$, which lasted for $3 \mathrm{~h}$. Almost 130 hectares of land and 37 buildings were flooded (out of which 15 were severely damaged), $14 \mathrm{~km}$ of roads were damaged or blocked and 140 inhabitants were evacuated. The discharge into the Manastirica River increased 815 times, from $\mathrm{Q}=0.19 \mathrm{~m}^{3} \mathrm{~s}^{-1}$ to $Q_{\operatorname{maxhMan}-1996}=154.9 \mathrm{~m}^{3} \mathrm{~s}^{-1}$. The water level increased from $30-40 \mathrm{~cm}$ to $6.2 \mathrm{~m}$ (Ristić et al., 1997b).

The realization of restoration works will help decrease annual yields of erosive material from $\mathrm{W}_{\mathrm{a}}=24357 \mathrm{~m}^{3}\left(825.7 \mathrm{~m}^{3} \times \mathrm{km}^{-2}\right) \quad$ to $\quad \mathrm{W}_{\mathrm{a}}=16198 \mathrm{~m}^{3}$ $\left(549.1 \mathrm{~m}^{3} \times \mathrm{km}^{-2}\right)$. The effects of hydrological changes were estimated through the comparison of the historical maximal discharge and the computed maximal discharge (under the conditions after the planned restoration). The value of the historical maximal discharge $\left(\mathrm{Q}_{\operatorname{maxhMan}}=154.9 \mathrm{~m}^{3} \times \mathrm{s}^{-1}\right)$ is significantly decreased after 


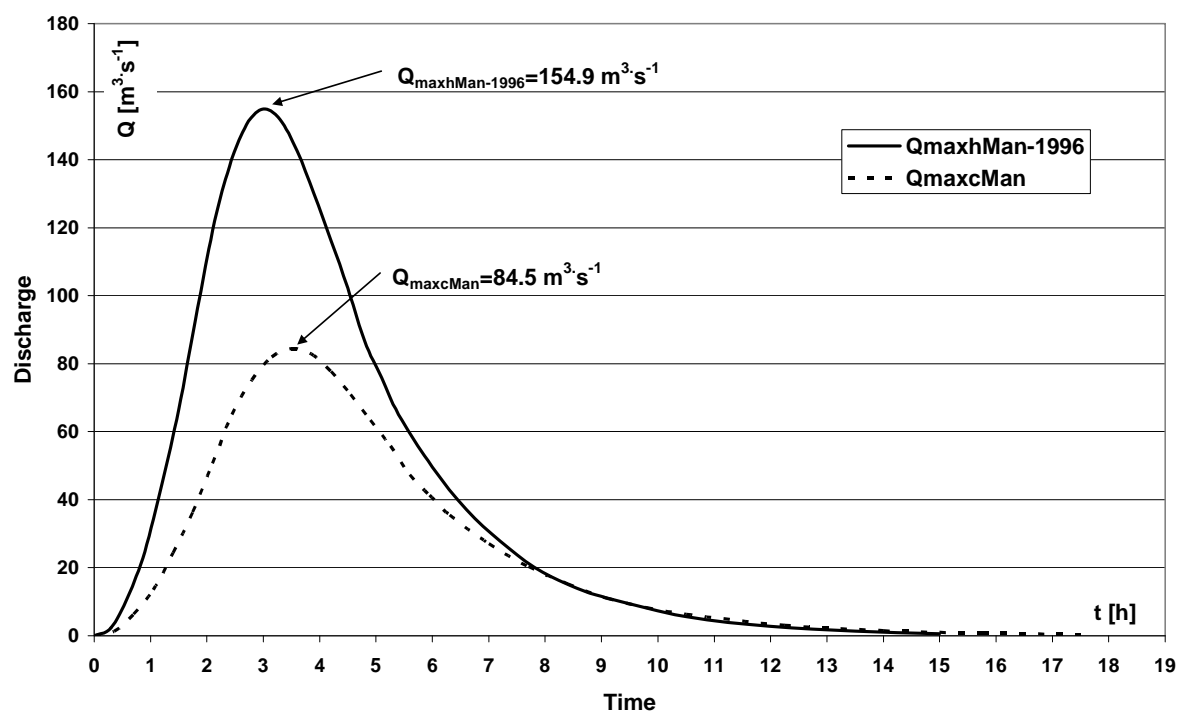

Fig. 6. Historical $\left(\mathrm{Q}_{\operatorname{maxhMan}-1996}\right)$ and computed $\left(\mathrm{Q}_{\operatorname{maxcMan}}\right)$ hydrographs of maximal discharges on the Manastirica River.

restoration $\left(\mathrm{Q}_{\max \mathrm{cMan}}=84.5 \mathrm{~m}^{3} \times \mathrm{s}^{-1}\right)$, which indicates an improvement in the hydrological conditions as a direct consequence of erosion and torrent control works (Fig. 6). At the same time, other significant parameters such as the main physical characteristics of the watershed and total precipitation remain the same.

\section{Final consideration}

Natural hazards cannot be prevented, but better understanding of the processes and scientific methodologies for prediction can help mitigate their impact (Alcantara, 2002). Authorities in some European countries have recognized the need to warn the public about the threats of flooding and highlight the need to use watersheds wisely (Pottier et al. 2005), whilst considering environmental protection and flood management as factors of a similar importance and the optimum flood control system as a compromise between these two competing objectives (Plate, 2002).

In most cases, torrential floods are caused by natural occurrences (such as the climatic, morphologic and hydrographic particularities of the watersheds), but human factors contribute significantly to the effects of the disasters (the mismanagement of forest and agricultural surfaces, uncontrolled urbanization, and the absence of erosion control and flood protection structures). Torrential floods are the most frequent catastrophic events that occur in Serbia in both urban and rural areas, with serious risks to people and their activities. These natural hazards have caused the death of more than 70 people in the last $60 \mathrm{yr}$ and material damage estimated at more than 8 billion euros.

The lack of a representative data base for determining the potential catastrophic maximal discharges influences the cre- ation of inappropriate perceptions of the risks, which can have fatal consequences. An extension of the observation system, especially over small watersheds $\left(A<10 \mathrm{~km}^{2}\right)$, with longer periods of observation, improved equipment (automatic water level recorders and rain-gauges and calibrated weather radars connected to one information center), as well as data collection regarding historical torrential floods (by the "hydraulic flood traces" method), all would combine to form a relevant data base that would improve the decision making process and represent a precious source for estimating possible catastrophic events. The forecast and simulation of torrential floods are essential for early flood warnings and planning of rescue operations. Particular attention needs to be paid to the characteristics of torrential flood waves, including their sudden appearance, destructivity, short duration and seasonal character.

Torrential floods need serious attention, with the following activities: identification of HZs and TAs (whole watersheds or certain parts), short term protection strategies, long term protection strategies, strictly controlled land use, risk management systems, along with public education and media coverage. The importance of PAERs and PPTFs is illustrated by the example of the Serbian capital, the city of Belgrade, with a territory of $3500 \mathrm{~km}^{2}$ and 190 torrents in both rural and highly urbanized areas. The Master Urbanistic plan of Belgrade was finished in 2002, but some solutions were not applicable because certain areas for residential and infrastructure construction were located in torrential flood zones or on landslides. This was evident during the heavy rain events and floods in 2003 and 2004. The authorities of the city of Belgrade decided to produce PAERs and PPTFs. These plans were finished during 2005 (The Faculty of Forestry and IWRMJČ, 2005) and their solutions were implemented 
in the Master Urbanistic Plan in order to eliminate the shortcomings of its former version. That served as the motivation for other municipalities in Serbia to start making PAERs and PPTFs. So far, 30 municipalities have produced the above mentioned plans, which cover about $22 \%$ of the territory of Serbia.

Development of HZs and TAs mapping and detailed risk assessment support a readiness for these disasters. HZs and TAs maps provide the basis for torrential flood prevention and mitigation by identifying "source" zones of impacts (fast surface runoff and sediment) and areas that are potentially exposed to flooding, which threatens the safety of human lives and property. These maps then guide the local authorities in adopting torrential flood management programs (through PAERs and PPTFs), including restoration measures, prevention, education and preparedness. Short term protection comprises of all measures that can be relatively promptly realized (in a period ranging from one month to one year), including good maintenance of regulated and natural torrent beds, administrative bans (on construction in flood zones and clear forest cutting on degraded slopes) and mandatory practices (controlled urbanization, contour or terrace farming). Long term protection includes: forming of reservoirs and retentions for the reception of torrential flood waves, dislocation of residential and infrastructure objects from flood zones, and effective erosion and torrent control of watersheds. The risk of fast surface runoff can be significantly decreased by changes in land use (afforestation of bare land, reclamation of degraded forests, meadows and pastures, siltfiltering strips, contour farming and terracing) in order to reduce erosive material production and meliorate water infiltration and water storage capacity of the soil. It is very important to inform and educate all stakeholders about these planned activities, provide subsidies for implementation and media support.

Integral planning and management at local and regional levels is very important in order to overcome the collapse of strategic thinking in Serbia in the past $20 \mathrm{yr}$, which has been reflected in many ways, especially in the domain of natural hazards prevention (Vujošević, 2010). All levels of planning (spatial, urbanistic, regulation) have to consider all the dominant factors for the initiation of erosion processes and fast surface runoff formation. Problems of erosion processes and protection from torrential floods in Serbia have been integrated into the spatial planning documents in the last few years. However, we need at least five years to improve that process, in accordance with the solutions from the latest "Draft of the Spatial Plan of the Republic of Serbia" (Republic Agency for Spatial Planning, 2010). Effective protection from torrential floods requires coordinated work in the fields of water resources management, forestry, agriculture, energetic, environmental protection and local economic development. PAERs and PPTFs should be integrated into Spatial Plans in order to improve the process of planning and aid in the establishment of sustainable solutions. The pre- vious Water Law (OG, 1991) defined that local authorities were obliged to make PAERs and PPTFs, but the funding for the intended solutions had to be provided by State authorities (The Directorate for Waters and the State-owned company "Serbian Waters"). The latest Water Law (OG, 2010) defines that the production and financing of PAERs and PPTFs, as well as the implementation of the intended solutions, have to be met at the local level. This is not a suitable solution if we take into consideration that local authorities, with negligible exceptions, do not have the financial and human resources (experts) needed for the application of ETCWs. Obviously, some changes of the existing Serbian Water Law are a necessity.

There is a Serbian tradition in the realization of ETCWs of longer than $100 \mathrm{yr}$, which has produced significant results. However, the existing level of investment $\left(1.045 \times 10^{6} €\right.$ epr yr) is not at a satisfactory level. Future financing has to be based on a much larger share of the Republic and regional funds and partly on the municipal funds, in order to reach the planned level of investments $\left(18.7 \times 10^{6} €\right.$ per yr) in erosion and torrent control.

Serbian society is changing towards the acceptance of European standards in all areas of public activity, and a part of this change is harmonization of legislation and practices in the field of flood prevention, with an emphasis on protection from torrential floods as the most common natural hazard in Serbia. Some European countries (Italy, Austria, Switzerland, France and Spain) have extensive experience in torrential watershed management. The application of certain positive experiences from these countries can improve torrential watershed management in Serbia. On the other hand, Serbia has achieved great success in the areas of erosion and torrent control with certain original solutions that might be of interest to the European scientists and professionals in this field. This paper is the first step in presenting the Serbian experience related to the issues of erosion and torrent control and a step towards the exchange of technical and scientific information between European countries and Serbia.

Acknowledgements. This study was supported by the Ministry of Education and Science of the Republic of Serbia within project 43007 ("Studying climate change and its influence on the environment: impacts, adaptation and mitigation-subproject: Frequency of torrential floods and degradation of soil and water as a consequence of global changes").

Edited by: F. Luino

Reviewed by: two anonymous referees 


\section{References}

Alcantara, A. I.: Geomorphology, natural hazards, vulnerability and prevention of natural disasters in developing countries, Geomorphology, 47, 107-124, 2002.

Ananda, J. and Herath, G.: Soil erosion in developing countries: a socio-economic appraisal, J. Environ. Manag., 68, 343-353, 2003.

Bakker, M., Govers, G., Kosmas, C., Vanacker, V., Oost, K., and Rounsevell, M.: Soil erosion as a driver of land-use change, Agriculture, Ecosyst. Environ., 105, 467-481, 2005.

Barredo, J. I.: Major flood disasters in Europe: 1950-2005, Nat. Hazards (Springer), 42, 125-148, 2007.

Berz, G., Kron, W., Loster, T., Rauch, E., Schimtschek, J., Schmieder, J., Siebert, A., Smolka, A., and Wirtz, A.: World Map of Natural Hazards - A Global View of the Distribution and Intensity of Significant Exposures, Natural Hazards (Kluwer Academic Publishers), 23, 443-465, 2001.

Chang, M.: Forest Hydrology, CRC Press, Washington D.C., 373 pp., 2003.

Djorović, M.: Determination of soil Hydrologic class, J. Water Resour. Manage., 87, 57-60, 1984.

European Environmental Agency: Coordination of information on the Environment, 152 pp., 1994.

Faculty of Forestry and Institute for Water Resources Management "Jaroslav Ćerni": Plans for announcement of erosive regions and Plans for protection from torrential floods, Belgrade, Serbia, 578 pp., 2005.

Fattorini, M.: Establishment of Transplants on Machine-Graded Ski Runs Above Timberline in the Swiss Alps, Restoration Ecology, 2, 119-126, 2001.

Freppaz, M., Lunardi, S., Bonifacio, E., Scalenghe, R., and Zanini, E.: Ski slopes and stability of soil aggregates, Adv. Geoecol., 35, 125-132, 2002.

Gavrilović, S.: Engineering of Torrents and Erosion, Journal of Construction (Special Issue), Belgrade, Yugoslavia, 292 pp., 1972.

Gavrilović, S.: Torrents in Serbia, Republic Water Fund and Faculty of Forestry, Belgrade, Yugoslavia, 149 pp., 1975.

Guzzetti, F., Stark, C., and Salvati, P.: Evaluation of Flood and Landslide Risk to the Population of Italy, Environ. Manag., 36(1), 15-36, 2005.

Institute for Water Resources Management ,Jaroslav Černi“: Water Resources Management Basic Plan of Serbia (WRMBPS), Ministry of Agriculture, Forestry and Water Resources Management, Belgrade, 369 pp., 2001.

Janković, D. and Malošević, D.: Anvelopes of specific maximal runoff in Serbia, Water Resour. Manage., 2, 21-39, 1989.

Janković, D.: Characteristics of intensive rainfall for territory of Serbia, Civil Egineering Almanac, Belgrade, Yugoslavia, 248268, 1994.

Jevtić, Lj.: Engineering Handbook for Torrent and Erosion Control, University of Belgrade Faculty of Forestry, Yugoslavia, Belgrade, 396 pp., 1978.

Jones, J. A., and Grant, G. E.: Peak flow response to clear-cutting and roads in small and large drainage basins, western Cascades, Oregon. Water Resour. Res., 32, 959-974, 1996.

Jones, J. A. and Post, D. A.: Seasonal and successional streamflow response to forest cutting and regrowth in the northwest and eastern United States, Water Resour. Res., 40, 19 pp., 2004.
Kostadinov, S., Zlatić, M., and Ranković, N.: Soil and Water Conservation Policies in Yugoslavia, Soil and Water Conservation Policies and Programs: Successes and Failures (Monograph), CRC Press, London, New York, Washington, D.C., 423-441, 1999.

Kostadinov, S.: Erosion and torrent control in Serbia: hundred years of experiences, International Conference: Erosion and Torrent Control as a Factor in Sustainable River Basin Management, Belgrade, Serbia, 25-27 September 2007, Proceedings (CD), 2007.

Kostadinov, S.: Torrents and Erosion, University of Belgrade Faculty of Forestry, Belgrade, 505 pp., 2008.

Kusky, M. T.: Encyclopedia of Earth and Space Science; Urbanization and Flash Flooding (pg. 282), Facts on File, Inc., Infobase Publishing, New York, 916 pp., 2010.

Lerner, L. A.: Assessing global exposure to natural hazards: Progress and future trends, Environ. Hazards, 7, 10-19, 2007.

Ministry of Agriculture, Forestry and Water Resources Management: Methodology for Plans for announcement of erosive regions and Plans for protection from torrential floods, Serbia, Belgrade, 89 pp., 1998.

Mosquera-Machado, S., and Dilley, M.: A comparison of selected global disaster risk assessment results, Nat. Hazards, 48(3), 439456, 2009.

Motha, J. A., Wallbrink, P. J., Hairsine, P. B., and Grayson, R. B.: Determining the sources of suspended sediment in a forested catchment in southeastern Australia, Water Resour. Res., 39(3), 4 pp., 2003.

Nondedeu, F. I., Rey, F., and Bedecarrats, A.: Contributions of vegetation cover and cattle hoof prints towards seed runoff control on ski pistes, Ecol. Eng., 27, 193-201, 2006.

Nondedeu, F. I. and Bédécarrats, A.: Influence of alpine plants growing on steep slopes on sediment trapping and transport by runoff, Catena, 71, 330-339, 2007.

Official Gazette of Republic of Serbia, 46, Water Law, 1827-1841, Belgrade, Serbia, 1991.

Official Gazette of Republic of Serbia, 30, Water Law, 81-100, Belgrade, Serbia, 2010.

Official Journal of the European Union: Directive 2007/60/EC on the assessment and management of flood risks, 288, 27-34, 2007.

Plate, E. J.: Flood risk and flood management, J. Hydrology, 267, 2-11, 2002.

Pottier, N., Penning, R. E., Tunstall, S., and Hubert, G.: Land use and flood protection: contrasting approaches and outcomes in France and in England and Wales, Appl. Geogr., 25, 1-27, 2005.

Republic Agency for Spatial Planning: Draft of Spatial Plan of the Republic of Serbia, Belgrade, 266 pp., 2010.

Republic Hydrometeorological Office of Serbia: Hydrologic annual reports-surface water, Belgrade, Serbia, 1946-2007.

Republic Hydrometeorological Office of Serbia: Hydrologic annual reports-precipitation, Belgrade, Serbia, 1945-2010.

Ristić, R., and Macan, G.: The Impact of erosion control measures on runoff Processes, Red Book - IAHS Publ., England, 245, 191-194, 1997a.

Ristić, R., Đeković, V., Nikić, Z., and Barbaroša, Z.: Reconstruction of torrential flood on the river Manastirica, ICFWST 97, Belgrade, Serbia, 29 September - 3 October 1997, 236-242, 1997b.

Ristić, R., Kostadinov, S., Malošević, D., and Spalević, V.: Erosion aspect in estimation of hydrologic soil group and determination of runoff curve number CN, Soil and Plant, 50(3), 165-174, 
2001.

Ristić, R. and Macan, G.: Investigation of interception in beech-fir stand on mountain Goè, J. Forestry Faculty, 86, 181-188, 2002.

Ristić, R.: Runoff lag time on torrential watersheds in Serbia, J. Faculty of Forestry, 87, 51-65, 2003.

Ristić, R., Gavrilović, Z, Stefanović, M., Malušević, I., and Milovanović, I.: Effects of urbanization on appearance of floods, BALWOIS, Ohrid, Macedonia, 23-26 May 2006, 7 pp., 2006.

Ristić, R. and Nikić, Z.: Sustainability of the System for Water Supply in Serbia from the aspect of Erosion Hazard, J. Water Resour. Manage., 225-227, 47-57, 2007.

Ristić, R. and Malošević, D.: Torrent hydrology, University of Belgrade Faculty of Forestry, Belgrade, Serbia, 221 pp., 2011 a.

Ristić, R., Marković, A., Radić, B., Nikić, Z., Vasiljević, N., Živković, N., and Dragićević, S.: Environmental Impacts in Serbian ski resorts, Carpath J. Earth Env., 6, 125-134, 2011 b.

Ristić, R., Radić, B., and Vasiljević, N.: Characteristics of maximal discharges on Torrential Watersheds in Serbia, J. Environ. Prot. Ecol., 12, 471-487, 2011c.

Schmidt, T. P., Greiving, S., Kallio, H., Fleischhauer, M., and Jarva, J.: Economic risk maps of floods and earthquakes for European regions, Quatern. Int.(Elsevier), 150, 103-112, 2006.
Soil Conservation Service: National Engineering Handbook, Section 4, Hydrology, US Department Agriculture, Washington, D.C., 364 pp., 1979.

Szendreine-Koren, E., Nemeskeri, I.: Water Management of forest soils below different soil types, Carpath J. Earth Env., 2, 17-24, 2007.

Toya, H. and Skidmore, M.: Economic development and the impacts of natural disasters, Economics Letters, 94, 20-25, 2007.

Troendle, C. A., and Olsen, W. K.: Potential effects of timber harvest and water management on stream flow dynamics and sediment transport, USDA Forest Service, General Technical Report, 247, 34-41, 1994.

Vujošević, M.: Collapse of Strategic Thinking, Research and Governance in Serbia and possible role of the Spatial Plan of the Republic Serbia in its renewal, SPATIUM International Review, 23, 22-29, 2010.

Wipf, S., Rixen, C., Fischer, M., Schmid, B., and Stoeckli, V.: Effects of ski piste preparation on alpine vegetation, J. Appl. Ecol., 42, 306-316, 2005. 